\title{
The Impact of the Multi-sensory Program Alfabeto on the Development of Literacy Skills of Third Stage Pre-school Children
}

\author{
Betina von Staa ${ }^{1}$, Loureni Reis ${ }^{1}$, and Matilde Conceição Lescano Scandola ${ }^{2}$ \\ ${ }^{1}$ Positivo Informática, Brazil \\ betina@educacional.com.br, loureni@positivo.com.br \\ ${ }^{2}$ Secretaria de Educação da Cidade de São Paulo, Brazil \\ mcscandola@prefeitura.sp.gov.br
}

\begin{abstract}
Here we present the results of the pilot-project undertaken in ten PreSchools with third stage (5 year-old) children who used ALFABETO Multisensory Program. The study shows that the project rendered meaningful results as to the development of writing hypotheses among the children who had access to the program. We also observed the opinions of the teachers involved in the project, who mentioned that ALFABETO motivated students to develop their reading, writing and oral skills, and promoted socialization and interaction among students.
\end{abstract}

Keywords: ALFABETO, Pre-School, Reading and Writing Skills, Interaction, Motivation.

\section{Introduction}

Alfabeto Multi-sensory Program (ALFABETO) combines educational software and hardware in a collaborative environment. It fosters the development of reading, writing and oral skills among students.

With this program, a group of students, mediated by their teacher, can participate in multi-sensorial activities that involve the manipulation of blocks that work together with a multimedia educational software. ALFABETO'S software is organized into themes, modules and environments. It contains activities at different levels, which involve the use of concrete materials and emphasize collaborative knowledge construction and interaction. The software allows the teachers to create their own activities by inserting pictures, sounds, and content to individualize students' learning. The software also supports students' learning with its intelligent multimedia feedback, which provides cues, written text and/or sounds while students progress through the program. If necessary, the software will display the correct answer to the exercise to encourage students to progress and avoid frustration.

The picture below shows a group of six students working together on ALFABETO. In their computer screen there is a picture of the heart that was drawn by the students and their teacher inserted it into the software through the configurator tool that comes 
with the Alfabeto software. The teacher also added the well-known Brazil song "Batatinha quando nasce" and the students recorded their voices reading/singing the lyrics. Through this collaborative work, the students are able to learn with familiar content that is motivating and meaningful for them. The picture illustrates students working on this customized activity and spelling the word "coração". They are working together to complete the lyrics by spelling with the blocks the selected words that appear on the screen in written form.

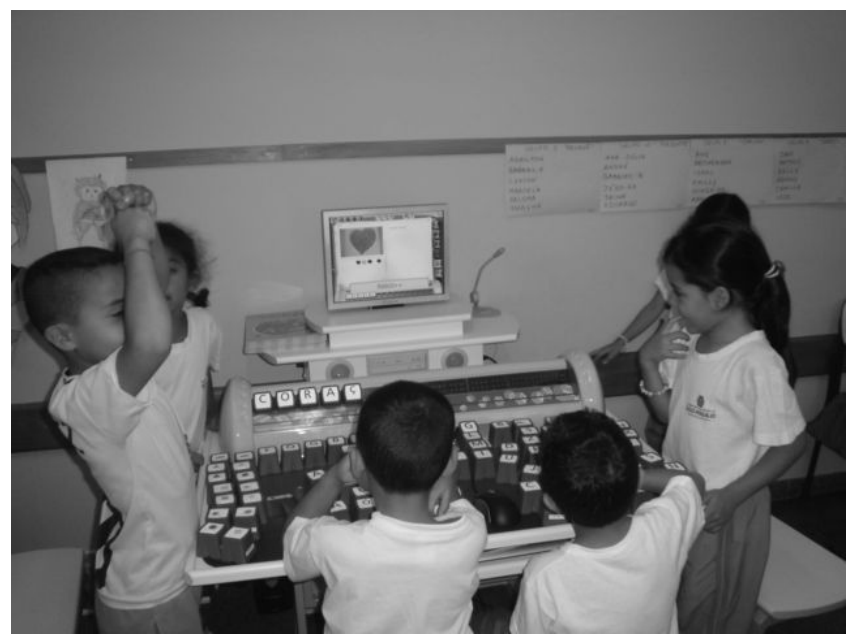

Fig. 1. Students cheering after having received positive feedback from ALFABETO

ALFABETO's multi-sensory panel recognizes the blocks through optic sensors, and the software, through PG (Patrulheiro das Galáxias), the speaking animated character in the program, who provides intelligent feedback to the children, rewarding them when they are right and guiding them when they need suggestions. The intuitive and manipulative nature of the interface makes it universally accessible. Students with limited previous exposure to Portuguese and to technology can all benefit from learning with Alfabeto.

ALFABETO's software offers activities that stimulate students' auditory, visual and kinesthetic learning styles. Age-appropriate sounds, animations, images, texts, words and letters motivate students to enhance their reading and writing skills. Teachers may include their own texts, sounds and animations into the software by means of the configurator to personalize students' learning. Thus, the teachers may adjust the content included in the program to their students' reading and writing skills and modify it through their learning process.

In 2008, the City of São Paulo Education Board requested a pilot-project to observe ALFABETO's impact in its own context, which is defined by teachers, parents, third stage students (5-year-old children) as well as by the physical location and space of the city's pre-schools, among other variables. During the pilot-project, we were supposed to observe ALFABETO's impact on third level pre-school children's reading and writing skills, as well as the teachers' attitudes towards the program. 
No one expected the 5-year-old students to be neither completely literate by the end of the pilot-project nor to achieve first-grade-level skills. After all, according to Toda Força ao $1 .^{\circ}$ ano [1], it is in the first grade that children should consolidate reading and writing skills. The task of the pre-school is to offer children meaningful contact with language in social context. Like the Education Board of the City of São Paulo states [2], we understand that "language is a discourse system that is organized during and for its written and spoken use, always in context." We also agree that "the knowledge about the writing system and the written language can and should be taught simultaneously." Like São Paulo [1] we understand that "the development of reading and writing skills is not a process that comes to an end when the student knows how to deal with the writing system, but it lasts for the whole life, enabling each person to take part in more situations that involve written language and to read and produce more texts of different genres, from literary to analytical works".

Here we present the results of ALFABETO's pilot-project undertaken in the City of São Paulo.

\section{Method}

We have performed a quasi-experimental study. Children of the focus group as well as the control group underwent pre- and post- writing tests. We relate these results to our field data, in order to understand, describe and justify them.

Third Stage students and their teachers in 10 different pre-schools in the city of São Paulo used ALFABETO for two months The project was undertaken in five schools in the Itaquera region and five the region of Campo Limpo. It involved 2,600 students, 75 teachers and 30 Alfabeto units.

It is important to mention that, in these regions, only $44 \%$ of the mothers and even fewer fathers have a High-School degree. The rest of the parents have had even less schooling. In this context, schools are responsible for assisting students in developing skills that most of their parents do not possess.

Each class had 35 students and one teacher. Children remained at school for 4 hours a day. During the time they stayed at school they received either breakfast, lunch or dinner.

All the teachers involved in this pilot-project, were invited to participate in an 8-hour training session and received daily visits from assistants during the pilotproject. They also received suggested lesson plans developed by Positivo Informática based on the City of São Paulo curriculum. The equipment was installed in the different schools according to their own request, taking into consideration the space they had available and the way each school organized its daily routine in classrooms and laboratories.

The data we had available for this study was collected through

1. Pre- and post- writing-hypothesis test of focus group and control group.

2. Teacher's questionnaires gathering opinions on the project as a whole, on their work, on how they felt towards the technological innovation, as well as on how they evaluated the students' attitudes and development in relation do ALFABETO. 
The writing-hypotheses assessments were undertaken before and after the students were introduced to Alfabeto. The study group included eight of the ten schools, all of which used ALFABETO. There were two control group-classes in two different schools which also received the pre-test as well as post-test. Students were supposed to answer five questions about their favorite friend, color, animal, toy/game and food by writing their answers. We evaluated whether they could write their own name, and whether they had a pre-syllabic, a syllabic, a syllabic-alphabetic or an alphabetic writing hypothesis ${ }^{1}$.

\section{Results}

Here we present the overall figures collected from the use of ALFABETO, the results of the pre- and post-test, as well as the opinions of the teachers.

\subsection{The Project in Numbers}

Here are our project's accomplishments in numbers:

- There were 1,317 classes during the two months of the pilot-project in the ten participating schools;

- Each student used the equipment 1.1 times a week, on average;

- $62 \%$ of the classes were planned using the configurator tool;

- $82 \%$ of the classes were prepared with the help of the assistant.

The above figures indicate that ALFABETO was used intensively, and was therefore relevant for the education of the children during the pilot-project.

${ }^{1}$ Toda Força ao $1 .{ }^{o}$ ano [3] defines the children's writing hypotheses as follows:

Pre-syllabic:

The child writes using graphic symbols.

The child uses letters to write.

The child writes different texts using different letters.

Syllabic:

The child establishes a relation between spoken and written language (for each spoken syllable, there is a symbol) using different graphic symbols.

The child establishes a relation between spoken and written language, using letters, but without using their conventional sounds.

The child establishes a relation between spoken and written language using the conventional sounds of the letters.

Syllabic-alphabetic:

The child establishes a relation between written and spoken language, using one letter per syllable or more.

Alphabetic:

The child writes alphabetically, even without observing conventional spelling rules.

The child writes alphabetically, observing some conventional spelling rules.

The child writes alphabetically, always observing conventional spelling rules. 


\subsection{Results of the Hypothesis-Test}

The Writing-hypothesis-test revealed a considerable increase in the number of students who knew how to write their own name, after they had access to ALFABETO. It also showed that many of these students developed the syllabic writing hypothesis. Some students also developed the syllabic-alphabetic hypothesis and some even showed to have an alphabetic hypothesis.

Below we present the results of the pre and post-test:

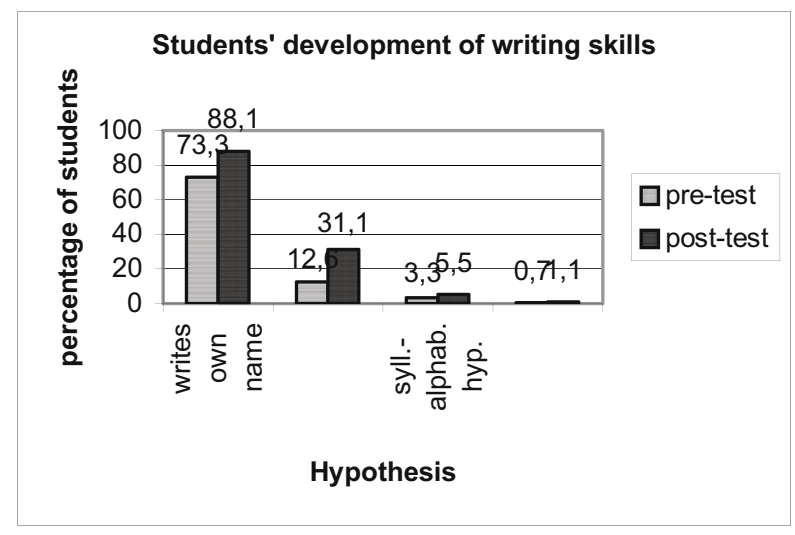

Fig. 2. Development of the writing hypotheses of focus group students between the pre-test and the post-test

From the eight schools that sent pre and post-test results, in seven of them students showed development. In one of the schools of the pilot-project as well as in the control group there was no difference between the pre and post-test numbers as to the skills of the students to write their own name or as to the development of any writing hypothesis.

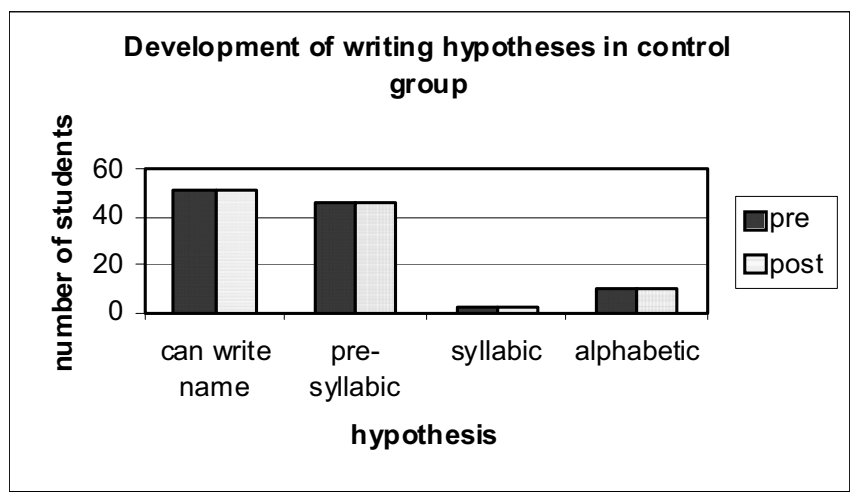

Fig. 3. Development of the writing hypotheses of control group students between the pre-test and the post-test 
If we compare these results to the ones obtained from the control group, which was undertaken exactly in the same period as the focus group, we have to infer that our results are very meaningful. The students in the control group did not show any development of their writing hypotheses and name-writing, while the students who had access to ALFABETO showed to understand the writing system faster and more confidently than those who had no access to the program. It is important to consider that the teachers received training to learn how to use the equipment and the software; they had daily access to assistants and received suggested lesson plans to use with their students. The teachers in the schools that showed no development in their students' writing skills did not take part in the initial 8-hour training. They allegedly had no time for it.

\subsection{The Teachers' Views}

When we analyzed the opinions of the 75 teachers involved in the pilot-project as to the impact of ALFABETO on the development of their students' skills, we observed that they enhanced and confirmed the results obtained by the writing-hypothesisassessment undertaken by the Board of Education of the City of São Paulo.

Here are our results:

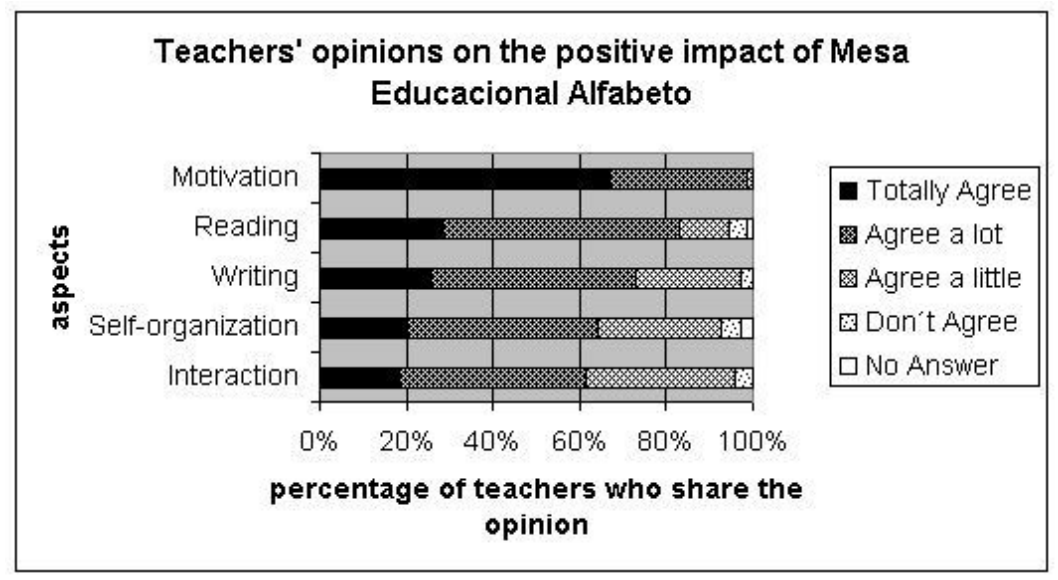

Fig. 4. Views of the teachers on the impact of Alfabeto Multi-sensory Program on their students' development. The questions that originated these results were: Motivation: ALFABETO motivated my students. Reading: My students felt more comfortable when reading at different moments in class.

Teachers have developed new ways of organizing their classes, with new activity structures for their lessons. They also noticed that the students took advantage from their time using ALFABETO because they were motivated and encouraged to develop their reading and writing skills, work on self-organization and work cooperatively. The graph above shows the degree of teachers' agreement that each different skill (reading, 
writing, self-organization, and interaction) is developed through the use of ALFABETO, as well as how much they believe the students are motivated by the program.

\subsection{Analysis of Teachers' Open Answers}

The open answers offered spontaneously by teachers who participated in the pilot-project also confirmed the quantitative data of this study. They reported that ALFABETO has contributed in many ways in the development of their students skills. ALFABETO is considered a rich, attractive and flexible program that stimulates participation, interest, attention and curiosity among students.

According to the teachers, ALFABETO develops students' reading, writing and oral skills, since it uses language with social functions, that are appropriate for preschool. Furthermore, teachers mentioned that ALFABETO also developed students' social skills, such as interaction, cooperation and sharing of knowledge. PG (Patrulheiro das Galáxias, the animated character that interacts with the students in the software) is referred to as playful and interactive.

Teachers reported that with ALFABETO, students developed their writing hypotheses, autonomy, self-organization and increased their comfort level with technology. The program is considered an ally for the teachers. They agreed that every aspect of ALFABETO contributed to children's literacy development.

They also noticed it was very important to work with ALFABETO in context and to take most advantage of it from the moment they had access to it.

They mentioned that in some cases, the students dealt with the equipment as if it were another toy, without understanding what it was for. At these moments, they considered it important to intervene and explain to the students what they were supposed to do with the program. Therefore, they concluded that the resource cannot be used by the children without teacher's surveillance. At the beginning, there seemed to be a belief on part of the teachers that students would be able to work by themselves on ALFABETO. In fact, this is not how the device is supposed to be used, and we are glad that the teachers noticed spontaneously that teachers' guidance was a necessary.

As to the teachers' difficulties to use ALFABETO, they considered the 8-hour training that was offered to them was too short to understand well how to use the equipment and they went through lots of trouble developing new ways to organize their classrooms and classes. Most of the teachers mentioned it was difficult to coordinate the students working with ALFABETO simultaneous with the other 30 students who were not working on the program.

Many teachers agreed that having an assistant help them prepare their classes, compensated for the brief training. After two months of effective use of ALFABETO, we noticed some teachers already knew how to use the configurator (which is the most sophisticated and complex teacher tool in the software) by themselves, but many others still had trouble using it. The teachers who did not take part in the initial 8-hour training had the most difficulties after two months.

The teachers mentioned that they would like to have more time to plan their classes, to work with fewer students in a classroom, and even to have less than six students per sensory panel. Many of them even worked ALFABETO regularly with four students per group. 
It is important to mention that ALFABETO demanded the greatest effort from the teachers at the beginning of the pilot-project. Teachers say that it was difficult to integrate their syllabus to ALFABETO's content. However, teachers came to the important conclusion that planning was absolutely essential for the success of ALFABETO in their classrooms. In fact, teachers were very satisfied to discover that they could plan a wide range of activities and personalize the program according to students' needs, in the same space and at the same time, for different groups of students, taking into account their individual pace.

\subsection{Solutions for Teachers' Difficulties}

As mentioned above, there were some difficulties that the teachers had to overcome during the study. Most of their difficulties were related to classroom organization and coordinating different students working simultaneously on different activities. Positivo Informática supported the teachers by sending them lesson plans for the students waiting for their turn to use ALFABETO. Some of the schools that participated in the study organized special spaces or centers in their classrooms or laboratories for the other students to work on relevant activities, while the other groups used ALFABETO. Some teachers planned complementary activities related to the ones they would work on with ALFABETO, and even introduced special materials for their students to provide them with opportunities to practice further and to consolidate their newly-acquired skills, keeping in mind their learning expectations. In a short time, all classrooms started working harmoniously and teachers and students were more satisfied and less anxious about integrating ALFABETO in their programs.

\section{Final Remarks}

We observed that ALFABETO is a motivating multi-sensory program that promotes the development of reading, writing and oral skills, at the same time that it develops students' social skills, such as interaction, autonomy, and self-organization. The program was also considered a rich and flexible educational tool, which was effectively explored by the teachers involved in the pilot-project. This means that the results presented here have most probably been influenced by the use of the ALFABETO program.

As to teachers' practice, the professionals involved noticed how important planning was for the success of their work. The teachers' difficulties were concentrated on how to organize their classes, since they always had a situation in which they had some students using the resource and others doing something else.

Nevertheless, most of the teachers, with the help of their assistants and coordinators, developed strategies to deal with simultaneous activities or centers in their classrooms. This was very satisfactory for everyone involved in the pilot-project, since the quantitative results showed such a meaningful development, which is the aim of the teachers, coordinators, parents and students alike.

We can thus conclude that the combination of quality resources, motivating and flexible software, as well as teacher training and assistance, can render extremely satisfactory results in a short period of time for the development of students' skills and teachers' practice, even in contexts that are far from ideal, but just real. 


\section{References}

1. SÃO PAULO (SP). Secretaria Municipal de Educação. Tempos e espaços para a infância e suas linguagens nos CEIs, Creches e EMEIs da Cidade de São Paulo. SME / DOT, São Paulo (2006)

2. SÃO PAULO (SP). Secretaria Municipal de Educação. Diretoria de Orientação Técnica. Orientações Curriculares: expectativas de aprendizagens e orientações didáticas para a Educação Infantil/ Secretaria Municipal de Educação. SME / DOT, São Paulo (2007)

3. BRASIL. Secretaria Municipal de Educação, Diretoria de Orientação Técnica, Círculo de Leitura e Escrita. Projeto Toda Força Para o 1. ${ }^{\circ}$ Ano: Guia para o planejamento do professor alfabetizador - orientações para planejamento e trabalho com o $1^{\circ}$ ano do Ensino Fundamental. SME/DOT, São Paulo (2006) 